\title{
A Study of the Effectiveness of Socio-Drama Learning Package in Promoting Environmental Knowledge and Behaviour of Secondary Schools Students in Osun State, Nigeria
}

\author{
Sofowora Olaniyi Alaba(Ph.D) \\ Omisope Kolawole Tayo

\begin{abstract}
Obafemi Awolowo University, Ile-Ife, Department of Educational Technology, Faculty of Education, Ile-Ife, Osun State, Nigeria
\end{abstract} \\ sofoworaolaniyi@gmail.com,oasofowora@yahoo.com/oasofowora@oauife.edu.ng
}

Doi:10.5901/mjss.2014.v5n23p1325

Abstract

The study developed an interactive socio- drama learning package for the teaching of Environmental Education concepts. It also examined the level of students' knowledge of and attitude to environmental education and determined the influence of the interactive socio- drama learning package in enhancing student's knowledge about the dangers of environmental hazards and pollution. These were with the view to ensuring sustainable and healthy environment. The study employed pre test, post test control group design. The population for the study consisted Junior Secondary School students in Atakumosa-West Local Government Area of Osun State. Two hundred JSS III students were randomly selected from four schools from this Local Government. These students were also randomly assigned to two groups i.e. the experimental and control groups. The students in the experimental group were exposed to the interactive drama learning package while the students in control group were taught Environmental Education concepts using the conventional method. Three instruments were used for data collection were (i) Survey questionnaire on students' prior knowledge of environmental education and environmental hazards (ii) Questionnaire on the effect of the interactive drama learning package on learning environmental education concepts ) (iii) Environmental Hazards Achievement Test. Data collected was analyzed using mean, standard deviation and t-test. The results showed that the interactive drama learning package was effective in the teaching of environmental education and useful in broadening students' knowledge about environmental pollution. The results also showed that the Interactive Socio- Drama Learning Package enhanced the academic performance of the students and changed their attitude positively.

Keywords: Socio-drama, Learning Package, sustainable development, environmental degradation and Environmental Education

\section{Introduction}

There is growing concern today about healthy and sustainable environment. The concern has to do with environmental degradation and reduction of Carbon dioxide $\left(\mathrm{CO}_{2}\right)$, global warming and other devastating effects resulting from human habits and behaviours. These negative impacts of human development and behaviours are manifolds in the area of deterioration of land, flooding, environmental pollution, erosion, earthquakes, water resources etc. The occurrences of natural disasters as a result of negative effect of man on the environment have raised global attention which led to several international conferences on sustainable environment. Hence, to many people all over the world the topics of environmental protection and sustainability have become important policy and legislation. These were reflected in different global efforts by the United Nations. [UNDESA,2006, Sofowora,2011].During the first worldwide meeting termed Nations Conference on Environment and Development (UNCED) held in Rio-De-Janiero in 1992, the Heads of States agreed to find lasting solution to the problem of environmental degradation. One of the agreements entered into that was relevant to this study was on sustainable development and biodiversity. This was identified as Agenda 21.Unfortunately, in spite of the different legislations, not many successes have been recorded in Nigeria. In the Country, environmental degradation continues as a result of people actions at the grass root because of their behaviours. To address this problem, a follow-up conference on sustainable development was held in Rio de Janeiro, Brazil where 192 Heads of States were in attendance. The Heads of States of the one hundred and ninety-two Countries in attendance renewed their commitments to the promotion of sustainable development.

The important issues addressed in this conference as related to healthy environment included:

1. new reliance on public transportation systems is being emphasized in order to reduce vehicle emissions, congestion in cities and the health problems caused by polluted air and smog; 
2. alternative sources of energy to replace the use of fossil fuels which are linked to global climate change;

3. growing concern to provide clean and drinkable water to the population;

4. reduce the prevalence of toxic wastes, such as lead in gasoline, or poisonous waste.

In spite of the move internationally, to ensure sustainable and healthy environment, little has been achieved in Nigeria due to poor Environmental Education. The uncollected urban and rural wastes, indiscriminate and unplanned construction of houses, refuse and bush burning, industrial pollution in the air, land and water, not only affects the physical environment but they also have deleterious effect on socio-economic life of the Nigerians. Another serious devastating environmental challenge is flooding. Between May and September 2012, there were many recorded cases of flooding. According to the National Emergency Management Agency (NEMA) the 2012 floods in Nigeria killed 363 people and displaced over 2,100,000 people. Not only this, agricultural produce were also affected. Its destructive effect on the economy cannot also be ignored. With the current state of Nigeria's environment, one can unequivocally argue that most Nigerian citizens lack knowledge of inherent dangers associated with poor and unhealthy environment. In response to this degradation and other environmental disasters, Nigeria through various organizations like National Emergency Management Agency (NEMA),National Orientation Agency (NOA) etc. started to encourage the general public to adopt sustainable habits and behaviours. Thus they advocated for Environmental Education at the grass root as the economic, best and most effective ways of ensuring sustainable environment.

\section{Review of Related Literature}

Literature has shown that behavioural change theories and models are very important for the alteration of individuals' behavioural patterns. In addition, many existing literature supports the assumption that increase in environmental knowledge will lead to change in behavior that will favour sustainability (Nutbeam 2000,Graefe and Volgelson 2007). It cited environmental, personal, and behavioural characteristics as the major factors in behavioural determination. Hence, the growing interest in recent years, in the application of these theories in the areas of Health and Environmental Education with the hope that understanding behavioural change will improve the attitude of the people at the grass roots towards ensuring a healthy and sustainable environment. According to Somanathan (2010), Environmental Education initiatives can be an important tool in addressing some of the major environmental problems facing developing countries. Subsequently, the knowledge gained through such information could lead to significant changes in people's environmental behaviour. Thus the need to critically focus on Nigeria's environmental sustainability in view of the recent environmental problems experienced. In support of this is Ogunleye (2004). The scholar attributed the prevalence of environmental devastation to lack of Environmental Education. She further argued that the continuous and indiscriminate dumping of household solid waste into open sewers is a typical example of their open and deliberate disregard for environmental rules. According to her, the people at the grass root lack environmental consciousness hence, there is need for more campaign to help change the behavior of the people at local community level.

To further explain behaviour necessary for environment, Nutbeam(2000) suggestion was used. This school of thought advocated for the amalgamation of the Social Learning Theory and Theory of Planned Behavior as the most appropriate way to improve Environmental Education. This is because the theories address the interaction between individuals and their environments. These theories can provide insight into the effectiveness of education programs given under specific set of predetermined conditions, like the social context in which a program will be initiated. Environmental Education (EE) is a new field introduced into the educational system in order to enhance the awareness of the people on environmental issues; it is also a way of finding lasting solution to the environmental problems and to develop in the people the skills to deal with environmental degradation. It is a new approach to education which is hoped will bring some solutions to the deteriorating relationship between man and the environment. It is sad to note that the desired results have not been achieved. In addition there have been series of environmental protection measures introduced in different States which include environmental sanitation exercises as abatement measure, environmental awareness campaign, environmental legislations, environmental policies, forestation and land reclamation. Some of these environmental protection measures failed as a result of many reasons. One of the reasons is insincerity of the government and the negative attitude of general public. This therefore necessitated a better approach termed socio-drama learning package as an innovative tool for improving student's knowledge and to change their behaviour about environmental hazards.

\subsection{Interactive Socio-drama in Teaching and Learning.}

Cossal,Ember,Groven and Hazel-wood(1996) defined socio-drama as a powerful teaching strategy that combined a case study approach with traditional role-play methodology to illustrate critical issues in life care. Building on principles of adult 
learning and communication skills, the socio-drama method enabled the skilled facilitator to draw on the learner's past experiences as resources for teaching and reflective practice. It is a method for exploring the conflicts and issues inherent in social roles. It is an extension of psycho-drama. According to Boal (1985), "socio-drama" depicts several theater techniques used in educational and training settings and can also be used as a form of therapy and political action, which is sometimes described as Guerilla Theater or invisible theater. Cossal also defined socio-drama as the utilization of some forms of theater or dramatic techniques dealing with a social issue or topic that impacts society on some level. Thus socio-drama, a form of educational theater or audience or interactive theater is issue based Prochaska (1986). This view was shared by Graefe and Vogel song (2007) that defined socio-drama as a group action method in which participant's acts out social situation spontaneously and discovers alternative ways of dealing with that problem. In the word of Commenius(1560-1670), drama is concerned with those aspects of roles that we share with others and helps people to express their thoughts and feelings, solve problems, and clarify values(Milton, Dukitt and Cameron(2006). Unlike simple role playing, socio-drama employs many specific techniques to deepen and broaden the action of the enactment. Some of these are: doubling, soliloquy and mirroring. Socio-drama is used with groups wishing to explore common issues in teams, organizations, community, educational and political contexts. It uses many of the same techniques as psycho-drama to enable individual and group learn and change.

\section{Specific Objectives}

The specific objectives of the research are to:

a) develop an Interactive Drama Learning Package for the teaching of environmental education concepts;

b) assess the level of students' knowledge of and attitude to environmental education;

c) determine the effect of the Interactive Drama Learning Package on students' knowledge and attitude to environmental protection;

d) examine the relationship between perceived increase awareness and behavioural changes that focuses on greater environmental sustainability.

\subsection{Research Questions}

To achieve the objectives of this study, the following research questions were raised

(i) what is the level of students' knowledge about environmental hazards?

(ii) will the interactive drama learning package increases the students' knowledge about Environmental Education?

(iii) is interactive learning package an effective approach to acquiring right attitude about Environmental Education concepts? and;

(iv) are there any relationship between perceived increase awareness and the behavioural changes that focus on environmental sustainability?

\section{Research Design}

The study employed pre - test, post - test control group design

\section{Research Instrument}

Four instruments and a researcher designed interactive socio-drama learning package on environmental hazards were used. The instruments are:

1) a survey questionnaire on student's prior knowledge about environmental hazards (SKEEHA). questionnaire on the effect of the interactive drama learning package on learning environmental education concepts (SIDALEPAEC;

2) Environmental Hazards Achievements Test (EHAT) which was used as a pretest and post test to determine students' knowledge about environmental hazards;

3) a package was developed which was termed interactive drama learning package. This package used the socio-drama techniques in a classroom setting dealing with topical issues affecting the society. It included real life situation scenes, improvisational dialogue and behavioural issues dealing with the environment. The drama package consisted of a guide for using the package and a workbook. Other topical issues included are: 
environmental hazards, its causes and effects on the society and environment. It also included a demonstration of the roles and responsibilities of students in stemming down environmental hazards in the society. Students also embarked on a group project using the approaches they were exposed to in solving environmental problems in their schools.

\subsection{Validation of the Instrument}

The validity of the instrument was determined using content validity. The package and the questionnaire were scrutinized for content by experts from the Departments of Educational Technology, Educational Foundations and Counselling, Institute of Education and Geography ,ObafemiAwolowo University, Ile-Ife . It was later shown to some selected secondary school teachers for their comments on the appropriateness of the instrument. Their evaluation, observations and suggestions were used to make the final draft used. In order to determine the reliability of the instruments a sample of twenty students from a separate school who were not part of the experiment were used. A test-retest method was adopted to determine the reliability of the instruments. After the treatment a reliability coefficient values of $0.75,0.85$ and 0.79 were obtained.

\subsection{Procedure for Data Collection}

Two schools were randomly selected from Atakumasa West Local Government Area These Schools were Atakumasa High School Osu and Community High School Osu forming the experimental and control groups. The experimental group was taught Environmental Pollution and hazards using the interactive socio-drama package while the control group was taught EE using the conventional method. The treatment covered a period of seven weeks. The first week was used for introduction and pre-test. Students in both groups were pre-tested to determine their entry behaviour using the pretest questions. The second, third, fourth and fifth weeks were used for teaching in both groups. The sixth week was used for revision while the seventh week was used to conduct the post test. The Questionnaires were administered in collaboration with the class teachers.

\section{Data Analysis}

Data was analyzed using descriptive and inferential statistics. The scales for the achievement test, the pre-test, post-test scores were converted into percentages. The means and the standard deviation of the test were computed. t- test was used to test if significant difference existed between the means.

\section{Findings and Discussions}

Table 7.1 Students Prior Knowledge about Environmental Hazards.

\begin{tabular}{|l|c|c|c|c|c|}
\hline \multirow{2}{*}{ Item } & \multicolumn{2}{|c|}{ Agree } & \multicolumn{2}{|c|}{ Disagree } & \multirow{2}{*}{ Total } \\
\cline { 2 - 5 } & $\mathrm{f}$ & $\%$ & $\mathrm{f}$ & $\%$ & \\
\hline Best way of disposing refuse is by dumping it inside a flowing river. & 75 & 37.4 & 125 & 62.6 & 200 \\
\hline Going toilet in the bush should be encouraged. & 101 & 50.7 & 99 & 49.3 & 200 \\
\hline The machine in industries and working generators can cause global warming. & 80 & 40 & 40 & 60 & 200 \\
\hline The refuse dumped in the river can float away during rainfall. & 119 & 59.5 & 81 & 40.5 & 200 \\
\hline Global warming and ozone layer depletion are world-wide environmental hazards. & 67 & 33.7 & 133 & 66.3 & 200 \\
\hline
\end{tabular}

From Table 7.1, it can be seen that $37.4 \%$ of students agreed that the best way of disposing refuse is by dumping it inside a flowing river while $62.6 \%$ disagreed. More than half of the students i.e. $50.7 \%$ agreed that going to toilet in the bush should be encouraged while $49.3 \%$ disagreed. Also $40 \%$ of students agreed that the machines in industries and working generators can cause global warming while $60 \%$ disagreed. Whether the refuse dumped in the river can float away during rainfall $59.5 \%$ agreed, while $40.5 \%$ disagreed. Also 33.7\% agreed that the global warming and ozone layer depletion are worldwide environmental hazards while $66.3 \%$ disagreed. From the results, it was discovered that few learners have the prior knowledge about Environmental Education and environmental hazards. Majority of the students did not know the negative effects of environmental hazards on environment and human beings in general. Based on the above, it can be concluded that the students have low knowledge of Environmental Education and hazards 


\subsection{Research Question 2}

Will the Interactive Drama Learning Package (IDLP) increase the students' knowledge about environmental education? The Data in the table 7.2 below presents the results.

Table 7.2: Impact of IDLP on Student's Knowledge

\begin{tabular}{|c|c|c|c|c|c|c|c|c|c|c|}
\hline \multirow{2}{*}{ Test } & \multirow{2}{*}{ Group } & \multirow{2}{*}{ No of student } & \multirow{2}{*}{$\begin{array}{c}\% \\
\text { passed }\end{array}$} & \multirow{2}{*}{$\%$ Failed } & \multirow{2}{*}{ Remark } & \multicolumn{2}{|c|}{ Summary Passed } & \multicolumn{2}{|c|}{ Summary Failed } & \multirow{2}{*}{ General Remark } \\
\hline & & & & & & Total & $\%$ & Total & $\%$ & \\
\hline \multirow{2}{*}{ pretest } & Experimental & 100 & 0 & 100 & Poor & \multirow{2}{*}{21} & \multirow{2}{*}{10.5} & \multirow{2}{*}{179} & \multirow{2}{*}{89.5} & \multirow{2}{*}{ poor } \\
\hline & Control & 100 & 21 & 79 & Poor & & & & & \\
\hline \multirow{2}{*}{ posttest } & Experimental & 100 & 98 & 2 & Excellent & \multirow{2}{*}{158} & \multirow{2}{*}{79} & \multirow{2}{*}{42} & \multirow{2}{*}{21} & \multirow{2}{*}{ excellent } \\
\hline & Control & 100 & 60 & 40 & Good & & & & & \\
\hline
\end{tabular}

Table 7.2 showed that the greater percentage of the students failed at the pretest level. Specifically 79 percent of the students failed the test while only 21 percent passed in the control group. This is an indication of poor knowledge about EE. However at the post-test level, there was a remarkable improvement among the participants in the experimental group; where 98 percent of samples passed and 60 percent passed in control group. This was a clear improvement in the knowledge of the students exposed to the interactive socio- drama learning package (IDLP) i.e. there is a drastic reduction in the failure rate from 100 percent to 2 percent on Environmental Education concepts. We can therefore conclude that the Interactive Drama Learning Package (IDLP) was an effective tool for increasing student's knowledge about EE.

\subsection{Research Question 3}

Is interactive drama learning package an effective approach to developing right attitude about Environmental Education concepts

Table 7.3: Effectiveness of Interactive Drama Leaning Package in Developing Right Attitude

\begin{tabular}{|l|c|c|c|}
\hline Item & Agree \% & Disagree \% & Total \\
\hline Recognition of behaviours that are labeled as high risk to environmental hazards through the IDLP & 89 & 11 & 100 \\
\hline Understanding of the potential negative consequences of environmental hazards through IDLP & 75 & 25 & 100 \\
\hline $\begin{array}{l}\text { The strategies employed in the IDLP have helped me to have new commitment to reducing } \\
\text { environmental hazard. }\end{array}$ & 77 & 23 & 100 \\
\hline
\end{tabular}

From table 7.3above, 89percent agreed that the Interactive Drama Learning Package (IDLP) has helped them to recognize behaviour that is labeled as environmental hazard while few 11 percent disagreed. Likewise, Seventy five percent also agreed that they now have the understanding of the potential negative consequences of environmental hazards through the Interactive Drama Learning Package (IDLP . Seventy seven percent of the respondents agreed that the actions and strategies employed in the IDLP helped them to have new commitment to reducing environmental hazards while 23 percent disagreed.

Table 7.4: IDLP and the Levels of Students Attitude about Environmental Education.

\begin{tabular}{|l|c|c|c|c|}
\hline Item & High \% & Moderate \% & Low \% & Total \\
\hline The attitude expected of me for enhancing sustainable environment is----- & 52 & 40 & 8 & 100 \\
\hline My interest in promoting a healthy environment in my locality is------ & 54 & 39 & 7 & 100 \\
\hline $\begin{array}{l}\text { My desiring to participate in enlightenment programme at ensure healthy and } \\
\text { sustainable environment is -- }\end{array}$ & 53 & 44 & 3 & 100 \\
\hline
\end{tabular}

From the table above $92 \%$ were positively disposed to enhancing sustainable environment while $8 \%$ of the students had low attitude. It was also revealed that $54 \%$ of the students that watched IDLP were highly motivated to promoting healthy environment in their community, $39 \%$ moderately and only $7 \%$ of them with low motivation. Although this may be seen as good omen, however more efforts should be put in place to encourage all the participants and local community to partake 
in activities that will promote healthy and sustainable environment. It is a thing of joy that there was a remarkable improvement in the disposition of the students as $53 \%$ showed high interest and $44 \%$ moderate interest to participate in enlightenment programmes to ensure healthy and sustainable environment .Based on the findings one can conclude that the Interactive Drama Learning Package (IDLP) was an effective approach to acquiring right attitude about Environmental Education concepts.

\section{Conclusion}

Based on the finding of this study, it was concluded that, Interactive socio-drama package was an effective, motivating tool for teaching and learning Environmental Education. There was a positive improvement in the behavior and attitude of the students towards ensuring healthy and sustainable environment. Also the different approaches embedded in the package, enhanced knowledge, attitude of students because it was participatory, motivating, creative and activity based.

\section{Recommendations}

The following recommendations were made: government should intensify its effort at ensuring a clean, healthy and sustainable environment. A better and more user friendly approach to stemming down environmental hazards should be employed, rather than the present fire brigade approach / politicization that have not yielded any positive result. Environmental Education should be made compulsory right from the primary school level to the university level. While competent teachers and technically good instructional materials be provided in schools for teaching EE. The government should pay more attention to conservation of the environment by providing constant electricity as a way to reducing carbon emission. State Governments and the local government have a big role to play by using sensitization and mobilization programmes at encouraging the citizenries to be willing to participate in efforts that will enhance healthy and sustainable environment. Government at all levels should provide empowerment progammes that will help reduce poverty rate if we are to achieve a healthy and sustainable environment. As a matter of urgency, the flaring of Gas by the Nigerian National Petroleum Corporation should be stopped. Urgent and concerted effort be made to reduce oil pollution in the country.

\section{References}

Boal, A (1985). Theatre of the oppressed published by Theatre communications group. New York

Cossal, M. Ember, S. Groven, L. and Hazel -Wood, J.(1996). Acting Out: The workbook a guide to the development and presentation of Issue: Oriented Audience - Interactive Improvisational theatre. United State of America. Taylor and Francis Group,

Commnius, D.(1592 -1670). Fabri production and Design Java. Hills Publisher.

Culen, G. R . (2005). The status of environmental education with respect to the goal of responsible citizenship behavior.In essential readings in environmental education $3^{\text {rd }}$ ed. (pp 37 - 45). Champaign: Stripes Published L.L.C

Graefe,D and Volgelson, H. (2007). Environmental Education as a catalyst for behavioural change: A study effects of coastwatch magazine on subscriber environmental knowledge and behavior. Proceedings of the Northeastern Recreation Research Symposium 277-282

Genovese, F (2008).. Behavioural change for combating climate change. DEC Community Education Branch

Milton,T. L, Duckitt, J and Cameron ,L. D. (2006). A Cross -cultural study of environmental motive concerns and their implications for pro-envinronmental behavior. Environmental Behaviour 38(6)745-767

Nutbeam ,D (2000). Health Literacy as a public goal: a challenge for contemporary health education and communication strategies into 21stcentury. Health Promotion International, 15(3) 259-267

Ogunleye F (2004). . Environmental sustainability in Nigeria: The "awareness" imperative. JSTOR: African Issues. 31/32

Prochaska,J.O.and Diclemente, C. C (1986). (1986). Towards a comprehensive model of change.InU.Miller and N,.Heater(eds) Treating addictive behaviours. New York Press,

Somanthan, E. (2010) Effects of information on environmental quality in developing countries. Review of environmental economics and policy, . 4(2).

Sofowora, O.A (2011). An empirical investigation into the effectiveness of socio- drama as a unique educational tool to initiate behavioral change and skill development among Village Health Workers. Proceedings of the Canadian International Conference in Education. Toronto, 605-609

UNDESA (2006) The Millennium Development Goal Reports .Retrieved from the internet http://unsstats.un.org/unsd/mdg/resources/ statistics/product/progress(MDGs Reportpdf

UNESCO (1981). Thilisi Declaration on Environmental Education. United nations Environment Program (UNEP,1978).) Environmental education and training in Africa. Retrieved from http://new.unep.org/documents/

UNESCO (1980) .Environmental Education in the light of Thbilisi Conference.POMS, UNESCO. 